\title{
Etomoxir-induced increase in UCP3 supports a role of uncoupling protein 3 as a mitochondrial fatty acid anion exporter
}

Citation for published version (APA):

Schrauwen, P., Schrauwen-Hinderling, V. B., Hesselink, M. K. C., Schaart, G., Kornips, C. F. P., Saris, W. H. M., Westerterp-Plantenga, M. S., \& Langhans, W. (2002). Etomoxir-induced increase in UCP3 supports a role of uncoupling protein 3 as a mitochondrial fatty acid anion exporter. Faseb Journal, 16(12), 16881690. https://doi.org/10.1096/fj.02-0275fje

Document status and date:

Published: 01/01/2002

DOI:

10.1096/fj.02-0275fje

Document Version:

Publisher's PDF, also known as Version of record

Please check the document version of this publication:

- A submitted manuscript is the version of the article upon submission and before peer-review. There can be important differences between the submitted version and the official published version of record.

People interested in the research are advised to contact the author for the final version of the publication, or visit the DOI to the publisher's website.

- The final author version and the galley proof are versions of the publication after peer review.

- The final published version features the final layout of the paper including the volume, issue and page numbers.

Link to publication

\footnotetext{
General rights rights.

- You may freely distribute the URL identifying the publication in the public portal. please follow below link for the End User Agreement:

www.umlib.nl/taverne-license

Take down policy

If you believe that this document breaches copyright please contact us at:

repository@maastrichtuniversity.nl

providing details and we will investigate your claim.
}

Copyright and moral rights for the publications made accessible in the public portal are retained by the authors and/or other copyright owners and it is a condition of accessing publications that users recognise and abide by the legal requirements associated with these

- Users may download and print one copy of any publication from the public portal for the purpose of private study or research.

- You may not further distribute the material or use it for any profit-making activity or commercial gain

If the publication is distributed under the terms of Article $25 \mathrm{fa}$ of the Dutch Copyright Act, indicated by the "Taverne" license above, 
The FASEB Journal express article 10.1096/fj.02-0275fje. Published online August 21, 2002.

\section{Etomoxir-induced increase in UCP3 supports a role of uncoupling protein 3 as a mitochondrial fatty acid anion exporter}

Patrick Schrauwen*, Vera Hinderling ${ }^{\star}$, Matthijs K. C. Hesselink ${ }^{\dagger}$, Gert Schaart ${ }^{\dagger}$, Esther Kornips*, Wim H. M. Saris*, Margriet Westerterp-Plantenga*, and Wolfgang Langhans

*Department of Human Biology, Maastricht University, Maastricht, The Netherlands; ${ }^{\dagger}$ Department of Movement Sciences, Maastricht University, Maastricht, The Netherlands; Institute of Animal Sciences, Swiss Federal Institute of Technology, 8092 Zürich, Switzerland

Corresponding author: Patrick Schrauwen, Nutrition and Toxicology Research Institute Maastricht (NUTRIM), Department of Human Biology, Maastricht University, P.O. Box 616, 6200 MD Maastricht, The Netherlands. E-mail: p.schrauwen@hb.unimaas.nl

\section{ABSTRACT}

The physiological function of human uncoupling protein-3 is still unknown. Uncoupling protein3 is increased during fasting and high-fat feeding. In these situations the availability of fatty acids to the mitochondria exceeds the capacity to metabolize fatty acids, suggesting a role for uncoupling protein-3 in handling of non-metabolizable fatty acids. To test the hypothesis that uncoupling protein-3 acts as a mitochondrial exporter of non-metabolizable fatty acids from the mitochondrial matrix, we gave human subjects Etomoxir (which blocks mitochondrial entry of fatty acids) or placebo in a cross-over design during a 36-h stay in a respiration chamber. Etomoxir inhibited $24-\mathrm{h}$ fat oxidation and fat oxidation during exercise by $\sim 14-19 \%$. Surprisingly, uncoupling protein-3 content in human vastus lateralis muscle was markedly upregulated within $36 \mathrm{~h}$ of Etomoxir administration. Up-regulation of uncoupling protein-3 was accompanied by lowered fasting blood glucose and increased translocation of glucose transporter-4. These data support the hypothesis that the physiological function of uncoupling protein-3 is to facilitate the outward transport of non-metabolizable fatty acids from the mitochondrial matrix and thus prevents mitochondria from the potential deleterious effects of high fatty acid levels. In addition our data show that up-regulation of uncoupling protein-3 can be beneficial in the treatment of type 2 diabetes.

Key words: fat oxidation $\bullet$ human $\bullet$ GLUT4 • translocation

$\mathrm{T}$ The human uncoupling protein-3 (UCP3) is a recently identified member of the uncoupling protein family, which is expressed primarily in skeletal muscle. The physiological function of UCP3 is still unresolved $(1,2)$. Due to its homology with the brown adipose tissuespecific uncoupling protein-1 (UCP1), UCP3 was suggested to be involved in human energy turnover and obesity $(3,4)$. However, mice lacking UCP3 have a normal metabolic rate and body weight $(5,6)$, and fasting, an energy preserving condition, rapidly up-regulates the expression of UCP3 (7), contradicting a role for UCP3 in the regulation of energy turnover. Rather, UCP3 
protein content is consistently up-regulated in situations in which fatty acid delivery to skeletal muscle exceeds the muscle's fat oxidative capacity, such as fasting, acute exercise, and high-fat feeding (7-9). On the other hand, a reduction of UCP3 protein content is observed in situations in which fat oxidative capacity is improved, such as after endurance training (10) and after weight reduction (11). Finally, we showed that UCP3 protein content is highest in type $2 b$ muscle fibers, which are characterized by a low capacity to oxidize fatty acids and therefore are unable to metabolize all cytosolic fatty acids (12). Together with the finding that UCP3 can transport fatty acid anions (13), these results suggest that UCP3 might be involved in the mitochondrial transport of non-metabolizable fatty acids (14).

The majority of the fatty acids in the cytoplasm are converted to their esterified form (fatty acylCoA) by the enzyme fatty acyl-CoA synthetase and then transported into the mitochondria by the enzyme carnitine-palmitoyl-transferase-1 (CPT1). Only in the esterified form, fatty acids can undergo $\beta$-oxidation. Fatty acids that cannot be esterified accumulate in the cytosol and these non-esterified fatty acids can enter the mitochondria by a so-called flip-flop mechanism (15). Due to the higher $\mathrm{pH}$ inside the mitochondrial matrix, part of these non-esterified fatty acids will be deprotonated, resulting in fatty acid anions. Because a fatty acid anion can neither be metabolized inside the matrix nor cross the inner mitochondrial membrane (16), they are trapped inside the matrix, where they can have deleterious effects on mitochondrial function, for example due to lipid peroxidation. To test whether UCP3 is indeed involved in the transport of nonmetabolizable fatty acid anions, we created a situation in which the concentration of nonmetabolizable fatty acids will increase, by reducing the fat oxidative capacity and hypothesized that UCP3 would be increased in such a situation. Therefore, we gave healthy volunteers Etomoxir, an inhibitor of CPT1 and thus of the of the transport of fatty acids into the mitochondria, and measured fat oxidation and UCP3 protein content in skeletal muscle.

\section{METHODS}

\section{Subjects}

Ten healthy, lean young men $\left(\mathrm{BMI}=21.8 \pm 0.3 \mathrm{~kg} / \mathrm{m}^{2}\right.$; age $=25.6 \pm 1.7 \mathrm{y}, \%$ type 1 fibers: 44.1 $\pm 3.5 \%$ ) participated in the study. The Medical Ethics Committee of the University of Maastricht approved the study, and subjects gave their written informed consent.

\section{Experimental design}

Each subject underwent two treatments in randomized order. Every treatment lasted for 5 days. To create a situation in which fat oxidative capacity was maximally utilized, subjects were provided with high-fat diets for consumption at home during three days. On the evening of the third day subjects entered the respiration chamber for a $36 \mathrm{~h}$ stay $(20.00-08.00 \mathrm{~h})$ to allow the continuous determination of fatty acid oxidation. During the stay in the respiration chamber, subjects again consumed a high-fat diet and they were given oral dosages of either Etomoxir (day 3: $75 \mathrm{mg}$ in the evening; day 4: $150 \mathrm{mg}$ in the morning and afternoon; and $75 \mathrm{mg}$ in the evening, day 5: $150 \mathrm{mg}$ in the morning) or placebo (same time schedule with the same amount of capsules, but not containing any drug) under supervision in randomized order. This resulted in a total Etomoxir dose of $600 \mathrm{mg}$ over the $36 \mathrm{~h}$ in the respiration chamber. A fasting blood sample was taken on the mornings of day 4 and day 5 . On day 5 at $08.00 \mathrm{~h}$ subjects left the respiration 
chamber and a muscle biopsy was taken. After this, subjects exercised on a cycle ergometer for 2 $\mathrm{h}$ at $50 \%$ of their predetermined maximal performance. During the exercise test, blood samples were taken every $30 \mathrm{~min}$ (at $\mathrm{t}=30,60,90$ and 120 minutes) and indirect calorimetry was performed every half-hour.

\section{Diets}

Metabolizable energy intake and macronutrient composition of the diet was calculated by using the Dutch food composition table (17). The high-fat diet consisted of 60 energy \% fat, 30 energy $\%$ carbohydrate, and 10 energy \% protein. Milk fat was excluded from the high-fat diet because of its high content in medium-chain fatty acids. This ensured that mainly long-chain fatty acids contributed to the fat content in the high-fat diet.

\section{Indirect calorimetry}

Oxygen consumption and carbon dioxide production were measured in a respiration chamber, as previously described (18). The respiration chamber is a $14 \mathrm{~m}^{3}$ room and is ventilated with fresh air at a rate of $70-80 \mathrm{l} / \mathrm{min}$. The ventilation rate is measured with a dry gas meter (Schlumberger, type G6, The Netherlands). The concentrations of oxygen and carbon dioxide are measured by using a paramagnetic $\mathrm{O}_{2}$ analyzer (Hartmann \& Braun, type Magnos G6, Germany) and an infrared $\mathrm{CO}_{2}$ analyzer (Hartmann \& Braun, type Uras 3G, Germany). Ingoing air was analyzed every 15 minutes and outgoing air once every 5 minutes. During exercise oxygen consumption and carbon dioxide production were measured using open circuit spirometry (Oxycon- $\beta$ Mijnhard, The Netherlands).

In the respiration chamber, subjects followed an activity protocol consisting of fixed times for breakfast, lunch, and dinner, sedentary activities and bench-stepping exercise (three times daily for $15 \mathrm{~min}$ ). Throughout the daytime, no sleeping or other exercise was allowed during the stay in the respiration chamber.

We measured 24-h substrate oxidation from $8.00 \mathrm{~h}$ on day 4 to $8.00 \mathrm{~h}$ on day 5 . Substrate oxidation during sleep was measured from $00.30 \mathrm{~h}$ to $7.00 \mathrm{~h}$. Carbohydrate, fat and protein oxidation were calculated by using $\mathrm{O}_{2}$-consumption, $\mathrm{CO}_{2}$-production and urinary nitrogen losses with the equations of Brouwer (19).

\section{Urinary nitrogen excretion}

During the stay in the respiration chamber, urine was collected in two batches, one from $20.00 \mathrm{~h}$ to $8.00 \mathrm{~h}$ and one over the subsequent $24-\mathrm{h}$ interval. Subjects were requested to empty their bladders at $8.00 \mathrm{~h}$. The urine produced was included in the urine sample of the previous batch. Samples were collected in containers with $10 \mathrm{~mL} \mathrm{H}_{2} \mathrm{SO}_{4}$ to prevent nitrogen loss through evaporation; volume and nitrogen concentration were measured, the latter by using a nitrogen analyzer (Carlo-Erba, type CN-O-Rapid).

\section{Blood analyses}

Venous blood samples $(10 \mathrm{~mL})$ were obtained in EDTA-tubes and immediately centrifuged at 
high speed for $10 \mathrm{~min}$. Plasma was frozen in liquid nitrogen and stored at $-80^{\circ} \mathrm{C}$ until analysis of glucose (Hexokinase method, Roche, Basel, Switzerland), free fatty acids (FFA)(Wako NEFA C test kit, Wako chemicals, Neuss, Germany), and beta-hydroxybutyrate (BHB) (20).

\section{Muscle biopsy and analysis}

Muscle biopsies were taken from the mid-thigh region from M. vastus lateralis according to the technique of Bergström. For Western-blot detection of UCP3 an affinity-purified rabbit polyclonal antibody (code: 1331, kindly provided from L.J. Slieker, Eli Lilly and Co., Indianapolis, IN) prepared against a 20 aa-peptide (human sequence aa 147-166), was used, as previously described (11). Fiber typing was performed by indirect immunofluoresence by using a mouse monoclonal IgM antibody against slow myosin (MHC1, A4.840, Developmental Hybridoma Bank, Iowa City, IA). Subcellular localization of GLUT4 was performed by indirect immunofluoresence by using an affinity-purified antibody (21). All samples were treated identical with regard to dilution of the antibody, incubation time, and camera settings (exposure time and gain). Quantitative image analysis to determine the green fluorescent GLUT4 signal in sarcoplasm and subsarcolemmal region was performed by using LUCIA G/F image analysis software.

\section{Statistical analysis}

Data are presented as mean \pm SE. Differences between Etomoxir and placebo were analyzed pairwise with Student's $t$-tests. A two-factor repeated measures ANOVA with interactions was used to detect treatment * time interactions in selected variables. When significant differences were found, a Bonferroni adjusted post hoc test was used to determine the exact location of the difference. Pearsons correlation coefficients were calculated to determine the relationship between selected variables. Outcomes were regarded as statistically significant if $P<0.05$.

\section{RESULTS}

\section{Substrate metabolism}

Twenty-four hour fat oxidation was reduced significantly, by $\sim 14 \%$ after Etomoxir administration (158 \pm 6 gram per $24 \mathrm{~h}$ with placebo vs. $136 \pm 5$ gram per $24 \mathrm{~h}$ with Etomoxir, $P<0.05$, Fig. $1 A$ ). As a result, 24-h carbohydrate oxidation was higher after Etomoxir (214 \pm 16 gram per $24 \mathrm{~h}$ with placebo vs. $252 \pm 12$ gram per $24 \mathrm{~h}$ with Etomoxir, $P<0.05$ ). Twenty-four hour protein oxidation was not affected by Etomoxir $(65 \pm 5$ gram per $24 \mathrm{~h}$ with placebo vs. $65 \pm$ 4 gram per $24 \mathrm{~h}$ with Etomoxir, NS).

During the first night in the respiration chamber, only a few hours after administration of the first dosage of Etomoxir or placebo, fat oxidation tended to be lower after Etomoxir administration, but the difference did not reach statistical significance $(142 \pm 7$ gram per $24 \mathrm{~h}$ with placebo vs. $130 \pm 6$ gram per $24 \mathrm{~h}$ with Etomoxir, $P=0.12$, Fig. $1 B$. However, fat oxidation was reduced significantly by $\sim 19 \%$ during the second night in the respiration chamber $(139 \pm 5$ gram per $24 \mathrm{~h}$ with placebo vs. $113 \pm 4$ gram per $24 \mathrm{~h}$ with Etomoxir, $P<0.005$, Fig. $1 B$ ). Again, the inhibition of fat oxidation resulted in an increase in carbohydrate oxidation, which was only significant during the second night (first night: $39 \pm 10$ gram per $24 \mathrm{~h}$ with placebo vs. $51 \pm 7$ gram per $24 \mathrm{~h}$ 
with Etomoxir, NS; second night: $37 \pm 9$ gram per $24 \mathrm{~h}$ with placebo vs. $70 \pm 7$ gram per $24 \mathrm{~h}$ with Etomoxir, $P=0.05$ ).

During the $2 \mathrm{~h}$ of exercise, fat oxidation gradually increased $(P<0.05)$, and there was a significant time*treatment effect $(P<0.05)$, indicating that this increase was attenuated after Etomoxir administration (Fig. 1C). Post-hoc testing revealed that the Etomoxir-induced reduction in fat oxidation reached significance at $\mathrm{t}=90(667 \pm 43 \mathrm{mg} / \mathrm{min}$ with placebo vs. $602 \pm$ $42 \mathrm{mg} / \mathrm{min}$ with Etomoxir, $P<0.05)$ and at $\mathrm{t}=120(730 \pm 45 \mathrm{mg} / \mathrm{min}$ with placebo vs. $641 \pm 49$ $\mathrm{mg} / \mathrm{min}$ with Etomoxir, $P<0.05)$. Carbohydrate oxidation during exercise was not affected by Etomoxir.

\section{Blood substrates}

Plasma FFA levels at rest were not significantly affected by Etomoxir administration (487 \pm 76 $\mu \mathrm{mol} / 1$ after Etomoxir vs. $382 \pm 44 \mu \mathrm{mol} / \mathrm{after}$ placebo, $N S$ ). During exercise, FFA increased from $359 \pm 55 \mu \mathrm{mol} / 1$ at $\mathrm{t}=30$ to $1002 \pm 109 \mu \mathrm{mol} / \mathrm{l}$ at $\mathrm{t}=120$ with placebo, but this increase during exercise tended to be more pronounced after Etomoxir $(380 \pm 59 \mu \mathrm{mol} / \mathrm{l}$ at $\mathrm{t}=30$ to 1122 $\pm 130 \mu \mathrm{mol} / 1$ at $\mathrm{t}=120$ with Etomoxir, $P=0.08)$. Fasting plasma glucose levels were significantly lower in the morning of day $5(4.60 \pm 0.14 \mathrm{mmol} / \mathrm{l}$ after Etomoxir vs. $4.84 \pm 0.13$ $\mathrm{mmol} /$ after placebo, $P<0.01)$. During exercise, glucose levels decreased in both treatments, but the decrease was much more pronounced after Etomoxir (from $4.6 \pm 0.1 \mathrm{mmol} / 1$ at $\mathrm{t}=30$ to $4.0 \pm$ $0.1 \mathrm{mmol} / 1$ at $\mathrm{t}=120$ with placebo and from $4.4 \pm 0.2 \mathrm{mmol} / 1$ at $\mathrm{t}=30$ to $3.5 \pm 0.1 \mathrm{mmol} / 1$ at $\mathrm{t}=$ 120 with Etomoxir, $P<0.05$ ). Plasma beta-hydroxybutyrate $(\mathrm{BHB})$ concentration both at rest and during exercise was not affected by Etomoxir.

\section{UCP3 protein content}

Etomoxir administration increased UCP3 protein content in all subjects, on average by $\sim 67 \%$, compared with placebo (72 \pm 8 arbitrary units after Etomoxir vs. $43 \pm 11$ arbitrary units after placebo, $P<0.0005$, Fig. 2). The increase in UCP3 induced by Etomoxir was negatively correlated with the Etomoxir induced decrease in fat oxidation both during the first $(\mathrm{r}=-0.77$, $P<0.05)$ and second night $(\mathrm{r}=-0.77, P<0.05$, Fig. 3$)$ in the respiration chamber and with $24-\mathrm{h}$ fat oxidation $(\mathrm{r}=-0.71, P<0.05)$. The Etomoxir-induced increase in UCP3 protein, correlated very strongly and negatively $(\mathrm{r}=-0.89, P<0.005)$ with the change in fasting BHB concentration between Etomoxir and placebo. There was no correlation between Etomoxir-induced increase in $\mathrm{UCP} 3$ protein and fiber type composition.

\section{GLUT 4 translocation}

To examine whether up-regulation of UCP3 following Etomoxir administration, as a secondary effect, promoted translocation of GLUT4 in human skeletal muscle, we visualized subcellular localization of GLUT4 by immunofluorescence. Quantitative image analysis of all fasting (preexercise) samples revealed that the ratio of the intensity of the green fluorescent GLUT4 signal in sarcolemma: sarcoplasm was significantly higher after Etomoxir compared with placebo (1.18 \pm 0.02 vs. $1.12 \pm 0.02, P<0.05)$, indicating increased recruitment of GLUT4 to the cell surface (Representative pictures after placebo and after Etomoxir are shown in Fig. 4). There was no correlation between Etomoxir-induced increase in GLUT4 translocation and fiber type composition. 


\section{DISCUSSION}

Soon after the discovery of human UCP3, indications were found that the primary physiological role of UCP3 is not the regulation of energy turnover, as would be predicted from its homology to UCP1. Thus, mice lacking UCP3 have a normal metabolic rate and body weight $(5,6)$, and fasting, an energy preserving condition, rapidly up-regulates the expression of UCP3 (7). Rather, several groups suggested a role for UCP3 in fatty acid handling $(7,22,23,24)$. Based on the finding that UCP3 content is high in situations in which fatty acid delivery to the muscle exceeds the oxidative capacity, we hypothesized that UCP3 functions as an outward transporter of nonesterified fatty acid anions from the mitochondrial matrix, thereby protecting mitochondria against accumulation of non-esterified fatty acids that entered the mitochondrial matrix by flipflop across the mitochondrial inner membrane (14). In the present study, we used Etomoxir to inhibit CPT1, thereby reducing the capacity of fatty acids to enter the mitochondria in a form (fatty acyl-CoA) in which they are available for oxidation. We observed that 24-h fat oxidation was reduced by $\sim 14 \%$. During the night, the contribution of fatty acids to total substrate oxidation increases and therefore fat oxidation was determined during each night separately. Already a few hours after the first dose of Etomoxir, during the first night in the respiration chamber, fat oxidation tended to be lower. During the second night, Etomoxir reduced fat oxidation by $\sim 19 \%$, illustrating a cumulative effect of repeated Etomoxir administration. It is well-documented that during moderate-intensity exercise both the relative contribution and the absolute rate of fatty acid oxidation are high (25). Again, Etomoxir could reduce fat oxidation in this situation. Together these data show that Etomoxir was effective in lowering fat oxidative capacity by $\sim 14-19 \%$, indicating that Etomoxir reduced the entry of esterified fatty acids into the mitochondria. For comparison, the complete absence of acetyl-CoA carboxylase, which indirectly inhibits CPT1, increases fat oxidation by 30\% (26), indicating that a $14-19 \%$ reduction in fat oxidation undeniably reflects an effective blockade of CPT1. Consequently, nonesterified (non-metabolizable) fatty acids accumulate in the cytoplasm and the entry of these non-esterified fatty acids into the mitochondrial matrix by flip-flop is increased.

Next, we examined whether this reduction in fat oxidative capacity would indeed lead to an increase in UCP3 protein content. Using Western blotting we found that Etomoxir administration increased UCP3 protein content in all subjects, on average by $\sim 67 \%$, compared with placebo. Because Etomoxir was not equally efficient in reducing fat oxidation in all subjects, we also examined whether the increase in UCP3 protein content after Etomoxir administration was related to the observed decrease in fat oxidation. We found that the increase in UCP3 induced by Etomoxir was negatively correlated with the Etomoxir induced decrease in fat oxidation, illustrating that the up-regulation of UCP3 after Etomoxir depends on the reduction of fat oxidative capacity.

When the breakdown of lipids predominates and/or oxaloacetate availability is reduced, acetyl$\mathrm{CoA}$ is diverted to the formation of beta-hydroxybutyrate (BHB) in the liver. Blocking CPT1 will therefore result in reduced $\mathrm{BHB}$ production. Because Etomoxir has equal affinity to inhibit CPT1 in liver and muscle, plasma BHB is an indirect indicator of the efficacy of CPT1-blockade in skeletal muscle. We observed that the change in fasting BHB concentration between Etomoxir and placebo correlated very strongly and negatively with the Etomoxir-induced increase in UCP3 protein, indicating that inhibition of entry of esterified fatty acids via CPT1 into the mitochondria is crucial for the increase in UCP3 content. 
The very pronounced and rapid increase of UCP3 protein content upon blocking CPT1 by Etomoxir in a situation where the entry of esterified (metabolizable) fatty acids into the mitochondria is reduced, supports our hypothesis that the physiological function of UCP3 is the outward transport of non-esterified fatty acid anions from the mitochondrial matrix. In the situation where CPT1 is blocked non-esterified (and thus non-metabolizable) fatty acids are likely to accumulate in the cytosol but can also enter the mitochondrial matrix by a so-called flip-flop mechanism (15), after which they will be deprotonated. UCP3 can protect mitochondria from these non-esterified fatty acids by providing outward transport of these fatty acid anions. This physiological function for UCP3 can also explain previous findings that UCP3 is upregulated in situations where fatty acid supply exceeds fat oxidation capacity (fasting, high-fat diet, T3 treatment, acute exercise), and that UCP3 is down-regulated in situations where fat oxidation capacity is improved (endurance training, weight reduction). The high expression of UCP3 in type IIB muscle fibers is also consistent with this hypothesis, especially because these muscle fibers, which are hardly able to oxidize fatty acids needs to be protected against mitochondrial non-esterified fatty acids accumulation. Outward transport of non-esterified fatty acid anions from the mitochondrial matrix by UCP3 has also been hypothesized by HimmsHagen et al. (27). However, it is of physiological relevance to note that they suggested that UCP3 exports fatty acid anions from the matrix, which are delivered by hydrolysis of fatty acylCoA by mitochondrial thioesterases, when fatty acids are the principal substrate utilized. Clearly, the presently observed up-regulation of UCP3 upon inhibition of fat oxidation by CPT1 blockade is not in line with their hypothesis, though we cannot exclude that under certain conditions the fatty acid anions exported by UCP3 are derived from hydrolysis of fatty acyl-CoA.

From the present study, we cannot deduce what the key regulatory signal is that induces the UCP3 gene after Etomoxir treatment. It has been shown before that plasma FFA are able to upregulate UCP3 mRNA expression (28), most likely because FFA are ligands for PPARs and the PPAR family has been shown to regulate UCP3 gene expression (29). However, UCP3 can also be increased when plasma FFA levels are unaltered. For example, the up-regulation of UCP3 after long-term high-fat diet can not necessarily be attributed to changes in plasma FFA levels, since on the long-term high-fat diet consumption does not increase fasting plasma FFA levels (9). Similarly, the down-regulation of UCP3 with endurance training is not accompanied by a reduction in plasma FFA levels (10). In the present study, fasting levels of plasma FFA were not significantly increased after Etomoxir treatment. However, it cannot be ruled out the intracellular fatty acid or fatty acyl-CoA levels might have increased upon Etomoxir treatment, and that accumulation of these metabolites is responsible for the up-regulation of UCP3, as was suggested by Cabrero et al. (30). Alternatively, Etomoxir treatment has been shown to increase intramyocellular triglyceride pools in rats (31) and involvement of the muscular triglycerides pools in the up-regulation of UCP3 is well possible. However, in this context it is important to note that endurance-trained athletes have low levels of UCP3 (10) despite having increased intramuscular triglyceride levels (32). It is therefore more likely that accumulation of one or more metabolites involved in fatty acid metabolism (such as fatty acyl-CoA), due to an imbalance between fat availability and fat oxidative capacity rather than increased muscular lipid storage is involved in the regulation of UCP3. Further studies are needed to reveal the exact signals responsible for up-regulation of UCP3 in situations where the availability of fatty acids to the mitochondria exceeds fat oxidative capacity.

As a consequence of the reduction in fat oxidative capacity, carbohydrate oxidation needs to 
increase to supply sufficient energy. Indeed, Etomoxir increased carbohydrate oxidation and reduced plasma glucose concentration, both at rest and during exercise. Regarding the latter it is interesting to note that mice overexpressing UCP3 are also characterized by lower plasma glucose levels and an improved glucose clearance rate (33). In L6 myotubes overexpression of UCP3 increases glucose uptake through an increased recruitment of glucose transporter-4 (GLUT4) to the cell surface (34). Therefore, we examined whether up-regulation of UCP3 following Etomoxir administration was accompanied by an increased translocation of GLUT4 in human skeletal muscle. Indeed, sarcolemmal staining was increased after Etomoxir, indicating increased recruitment of GLUT4 to the cell surface. However, whether the up-regulation of UCP3 and increased GLUT4 translocation are related events cannot be deduced from the present study. For example, it is not clear from the present study whether Etomoxir induced regulation of UCP3 and GLUT4 is similar in different fiber types, and therefore further studies are needed to examine the relationship between UCP3 and GLUT4 in single muscle fibers.

In conclusion, we here present for the first time support for a novel physiological function of the human uncoupling protein 3 as an exporter of fatty acid anions. This physiological function of UCP3 can explain the majority of the findings on UCP3 regulation under different (physiological) conditions. Still, UCP3 could act as an uncoupling protein, since the outward transport of fatty acid anions actually decreases the proton gradient across the mitochondrial membrane, thereby uncoupling mitochondrial respiration, explaining the previously observed association of UCP3 with energy metabolism $(33,35)$. As a secondary effect, up-regulation of UCP3 was accompanied by GLUT4 translocation. Given that UCP3 protein content is decreased in type 2 diabetic subjects (36), UCP3 might be an important pharmaceutical target in the treatment of type 2 diabetes mellitus.

\section{ACKNOWLEDGMENTS}

P.S. was supported by a grant from the Netherlands Organization for Scientific Research (NWO). We thank Lawrence J. Slieker from Eli Lilly and Company for providing us with the UCP3 antibody. This work was supported by a grant from the Human Nutrition Institute of the International Life Sciences Institute Research Foundation (ILSI RF). The opinions expressed herein are those of the author(s) and do no necessarily represent the views of ILSI RF.

\section{REFERENCES}

1. Gong, D.-W., He, Y., Karas, M., and Reitman, M. (1997) Uncoupling protein-3 is a mediator of thermogenesis regulated by thyroid hormone, 33 -adrenergic agonists, and leptin. $J$ Biol Chem 272, 24129-24132

2. Boss, O., Samec, S., Paoloni-Giacobino, A., Rossier, C., Dulloo, A., Seydoux, J., Muzzin, P., and Giacobino, J.-P. (1997) Uncoupling protein-3: a new member of the mitochondrial carrier family with tissue-specific expression. FEBS Lett 408, 39-42

3. Schrauwen, P., Walder, K., and Ravussin, E. (1999) Human uncoupling proteins and obesity. Obes Res 7, 97-105

4. Ricquier, D., and Bouillaud, F. (2000) The uncoupling protein homologues: UCP1, UCP2, UCP3, StUCP and AtUCP. Biochem J 345, 161-179 
5. Gong, D.W., Monemdjou, S., Gavrilova, O., Leon, L.R., Marcus-Samuels, B., Chou, C.J., Everett, C., Kozak, L.P., Li, C., Deng, C. (2000) Lack of obesity and normal response to fasting and thyroid hormone in mice lacking uncoupling protein-3. J Biol Chem 275, 16251-16257

6. Vidal-Puig, A.J., Grujic, D., Zhang, C.Y., Hagen, T., Boss, O., Ido, Y., Szczepanik, A., Wade, J., Mootha, V., Cortright, R. (2000) Energy metabolism in uncoupling protein 3 gene knockout mice. J Biol Chem 275, 16258-16266

7. Millet, L., Vidal, H., Andreelli, F., Larrouy, D., Riou, J.-P., Ricquier, D., Laville, M., and Langin, D. (1997) Increased uncoupling protein-2 and -3 mRNA expression during fasting in obese and lean humans. J Clin Invest 100, 2665-2670

8. Schrauwen, P., Hesselink, M.K.C., Vaartjes, I., Kornips, E., Saris, W.H.M., Giacobino, J.-P., and Russell, A. (2002) The effect of acute exercise on uncoupling protein 3 is a fat metabolism mediated effect. Am J Physiol Endocrinol Metab 282, E11-E17

9. Schrauwen, P., Hoppeler, H., Billeter, R., Bakker, A., and Pendergast, D. (2001) Fiber type dependent upregulation of human skeletal muscle UCP2 and UCP3 mRNA expression by highfat diet. Int J Obes Relat Metab Disord 25, 449-456

10. Schrauwen, P., Troost, F.J., Xia, J., Ravussin, E., and Saris, W.H.M. (1999) Skeletal muscle UCP2 and UCP3 expression in trained and untrained male subjects. Int $J$ Obes Relat Metab Disord 23, 966-972

11. Schrauwen, P., Schaart, G., Saris, W.H.M., Slieker, L.J., Glatz, J.F.C., Vidal, H., and Blaak, E.E. (2000) The effect of weight reduction on skeletal muscle UCP2 and UCP3 mRNA expression and UCP3 protein content in type II diabetic subjects. Diabetologia 43, 1408-1416

12. Hesselink, M.K., Keizer, H.A., Borghouts, L.B., Schaart, G., Kornips, C.F., Slieker, L.J., Sloop, K.W., Saris, W.H., and Schrauwen, P. (2001) Protein expression of UCP3 differs between human type 1 , type $2 \mathrm{a}$, and type $2 \mathrm{~b}$ fibers. FASEB $J 15,1071-1073$

13. Jezek, P., Engstová, H., Zácková, M., Vercesi, A.E., Costa, A.D.T., Arruda, P., and Garlid, K.D. (1998) Fatty acid cycling mechanism and mitochondrial uncoupling proteins. Biochim Biophys Acta 1365, 319-327

14. Schrauwen, P., Saris, W.H., and Hesselink, M.K. (2001) An alternative function for human uncoupling protein 3: protection of mitochondria against accumulation of nonesterified fatty acids inside the mitochondrial matrix. Faseb J 15, 2497-2502.

15. Hamilton, J.A., and Kamp, F. (1999) How are free fatty acids transported in membranes? Is it by proteins or by free diffusion through the lipids? Diabetes 48, 2255-2269

16. Jezek, P., Orosz, D.E., Modriansky, M., and Garlid, K.D. (1994) Transport of anions and protons by the mitochondrial uncoupling protein and its regulation by nucleotides and fatty acids. A new look at old hypotheses. J Biol Chem 269, 26184-26190 
17. Stichting-Nederlands-Voedingsstoffenbestand. 1993. NEVO Tabel. Voorlichtingsbureau voor de voeding, Den Haag.

18. Schoffelen, P.F., Westerterp, K.R., Saris, W.H., and Ten Hoor, F. (1997) A dual-respiration chamber system with automated calibration. J Appl Physiol 83, 2064-2072

19. Brouwer, E. (1957) On simple formulae for calculating the heat expenditure and the quantities of carbohydrate and fat oxidized in metabolism of men and animals, from gaseous exchange (oxygen intake and carbonic acid output) and urine-n. Acta Physiol Pharmacol Neerlandica 6, 795-802

20. Moore, J.J., Marcus, M., and Sax, S.M. (1982) Kinetic assay of beta-hydroxybutyrate in plasma with a COBAS-BIO centrifugal analyzer. Clin Chem 28, 702-703.

21. Borghouts, L.B., Schaart, G., Hesselink, M.K., and Keizer, H.A. (2000) GLUT-4 expression is not consistently higher in type-1 than in type-2 fibres of rat and human vastus lateralis muscles; an immunohistochemical study. Pflugers Arch 441, 351-358.

22. Samec, S., Seydoux, J., and Dulloo, A.G. (1998) Role of UCP homoloques in skeletal muscles and brown adipose tissue: mediators of thermogenesis or regulators of lipids as fuel substrate? FASEB J 12, 715-724

23. Weigle, D.S., Selfridge, L.E., Schwartz, M.W., Seeley, R.J., Cummings, D.E., Havel, P.J., Kuijper, J.L., and BertrandelRio, H. (1998) Elevated free fatty acids induce uncoupling protein 3 expression in muscle. A potential explanation for the effect of fasting. Diabetes 47, 298-302

24. Argyropoulos, G., Brown, A.M., Willi, S.M., Zhu, J., He, Y., Reitman, M., Geveo, S.M., Spruill, I., and Garvey, W.T. (1998) Effects of mutations in the human uncoupling protein 3 gene on the respiratory quotient and fat oxidation in severe obesity and type 2 diabetes. $J$ Clin Invest 102, $1345-1351$

25. Saltin, B., and Åstrand, P.-O. (1993) Free fatty acids and exercise. Am J Clin Nutr 57, 752S$758 \mathrm{~S}$

26. Abu-Elheiga, L., Matzuk, M.M., Abo-Hashema, K.A., and Wakil, S.J. (2001) Continuous fatty acid oxidation and reduced fat storage in mice lacking acetyl-CoA carboxylase 2. Science 291, 2613-2616

27. Himms-Hagen, J., and Harper, M.E. (2001) Physiological role of UCP3 may be export of fatty acids from mitochondria when fatty acid oxidation predominates: an hypothesis. Exp Biol Med (Maywood) 226, 78-84.

28. Khalfallah, Y., Fages, S., Laville, M., Langin, D., and Vidal, H. (2000) Regulation of uncoupling protein-2 and uncoupling protein-3 mRNA expression during lipid infusion in human skeletal muscle and subcutaneous adipose tissue. Diabetes 49, 25-31

29. Emilsson, V., O'Dowd, J., Wang, S., Liu, Y.L., Sennitt, M., Heyman, R., and Cawthorne, M.A. (2000) The effects of rexinoids and rosiglitazone on body weight and uncoupling protein isoform 
expression in the Zucker fa/fa rat. Metabolism 49, 1610-1615.

30. Cabrero, A., Alegret, M., Sanchez, R., Adzet, T., Laguna, J.C., and Vazquez, M. (2001) Uncoupling protein-3 mRNA up-regulation in $\mathrm{C} 2 \mathrm{C} 12$ myotubes after etomoxir treatment. Biochim Biophys Acta 1532, 195-202.

31. Dobbins, R.L., Szczepaniak, L.S., Bentley, B., Esser, V., Myhill, J., and McGarry, J.D. (2001) Prolonged inhibition of muscle carnitine palmitoyltransferase-1 promotes intramyocellular lipid accumulation and insulin resistance in rats. Diabetes 50, 123-130

32. Hoppeler, H. (1986) Exercise-induced ultrastructural changes in skeletal muscle. Int J Sports Med 7, 187-204

33. Clapham, J.C., Arch, J.R., Chapman, H., Haynes, A., Lister, C., Moore, G.B., Piercy, V., Carter, S.A., Lehner, I., Smith, S.A. (2000) Mice overexpressing human uncoupling protein-3 in skeletal muscle are hyperphagic and lean. Nature 406, 415-418

34. Huppertz, C., Fischer, B.M., Kim, Y.B., Kotani, K., Vidal-Puig, A., Slieker, L.J., Sloop, K.W., Lowell, B.B., and Kahn, B.B. (2001) Uncoupling protein 3 (UCP3) stimulates glucose uptake in muscle cells through a phosphoinositide 3-kinase-dependent mechanism. J Biol Chem 276, $12520-12529$.

35. Bouchard, C., Pérusse, L., Chagnon, Y.C., Warden, G., and Ricquier, D. (1997) Linkage between markers in the vicinity of the uncoupling protein 2 gene and resting metabolic rate in humans. Hum Mol Genet 6, 1887-1889

36. Schrauwen, P., Hesselink, M.K.C., Blaak, E.E., Borghouts, L.B., Schaart, G., Saris, W.H.M., and Keizer, H.A. (2001) Uncoupling protein 3 content is decreased in skeletal muscle of patients with type 2 diabetes. Diabetes 50, 2870-2873 
Fig. 1
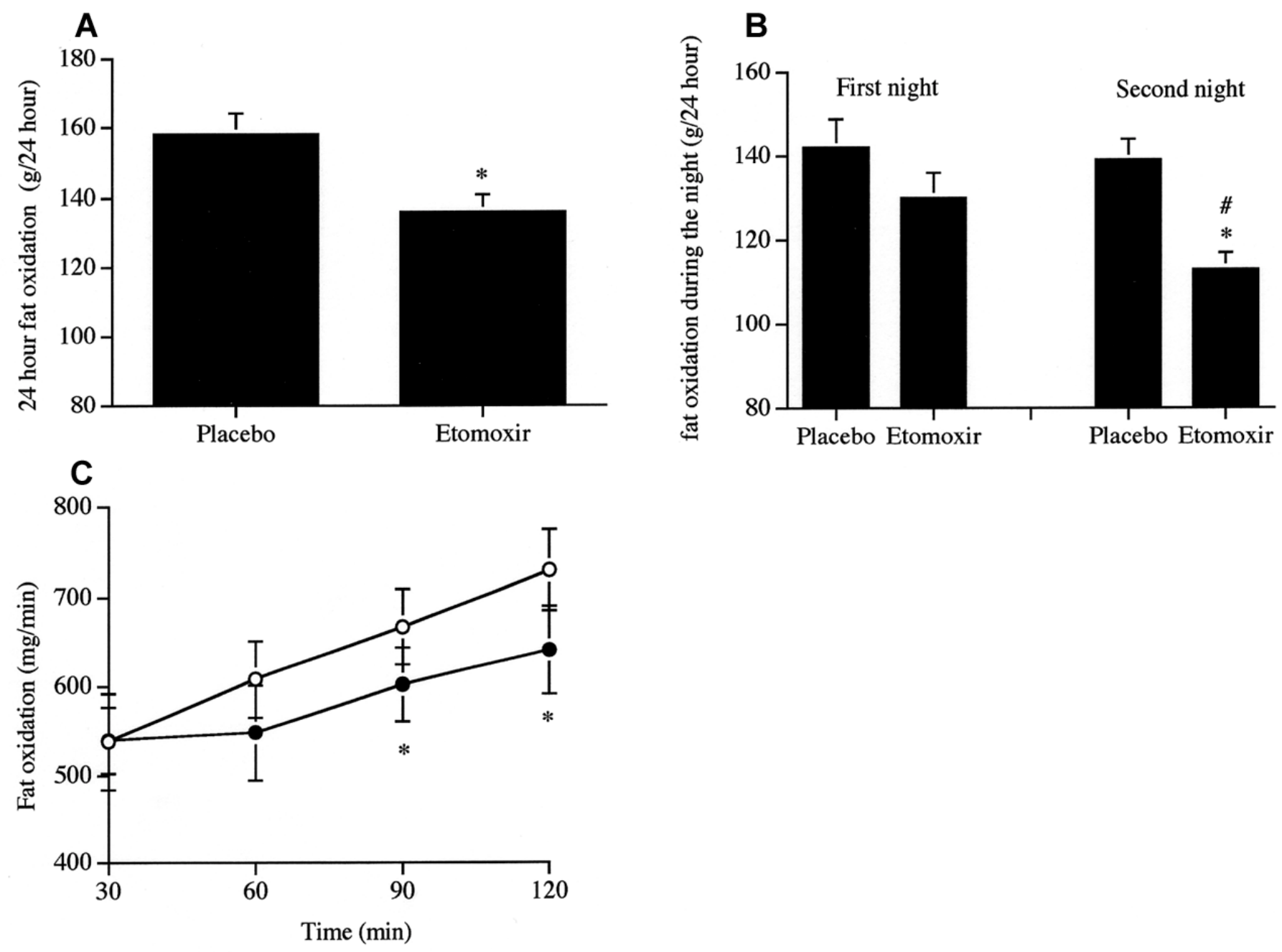

Figure 1. Effect of Etomoxir. On A) 24-h fat oxidation, B) fat oxidation measured during the night, and C) fat oxidation during exercise. Fat oxidation was calculated from oxygen consumption and carbon dioxide production, measured by indirect calorimetry. Open circles, placebo; solid circles, Etomoxir. ${ }^{*} P<0.05$ Compared with placebo. $\# P<0.05$ compared with night 1 . 
Fig. 2

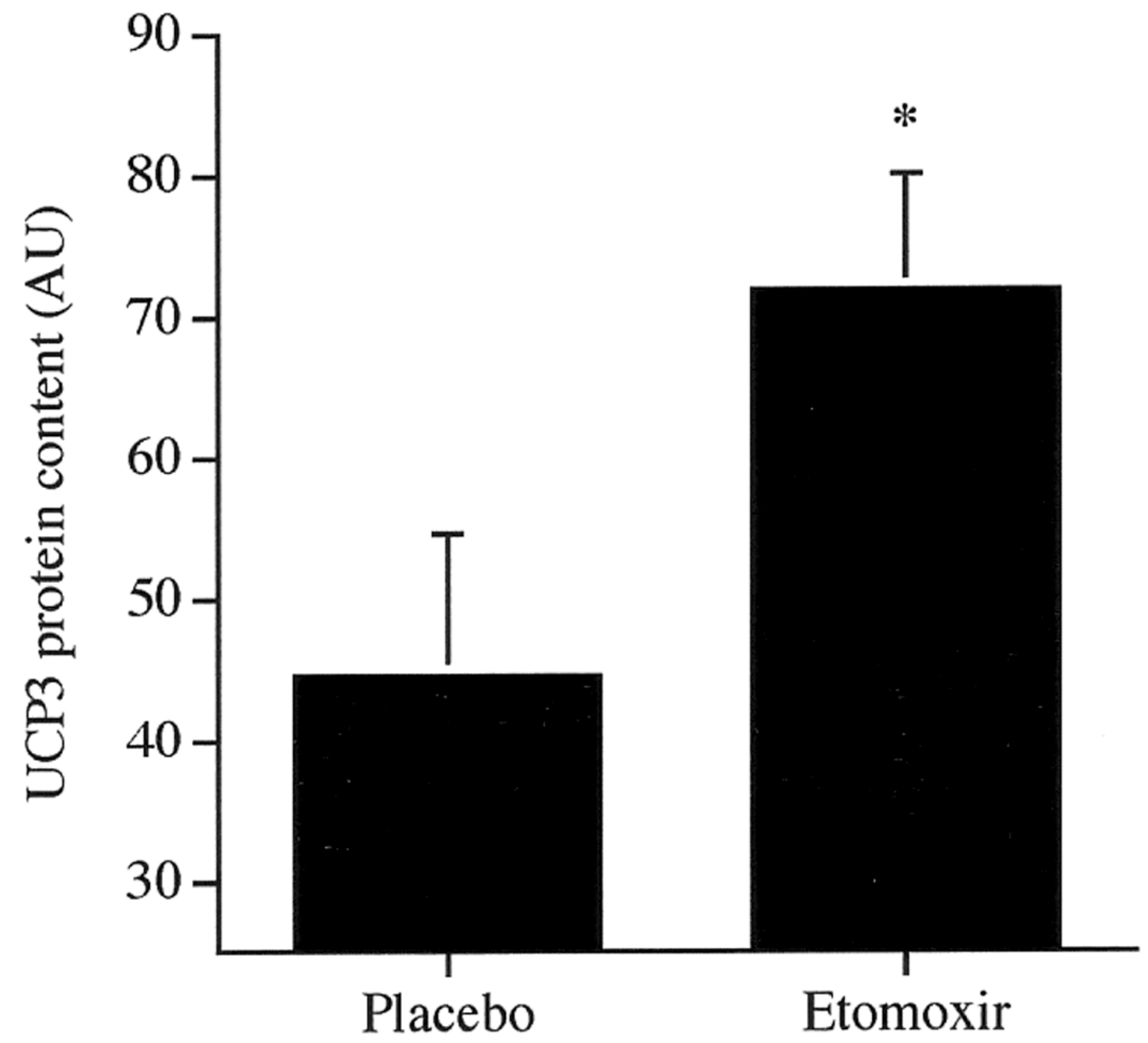

Figure 2. Effect of Etomoxir on UCP3 protein content (arbitrary units). ${ }^{*} P<0.0005$ compared with placebo. 
Fig. 3

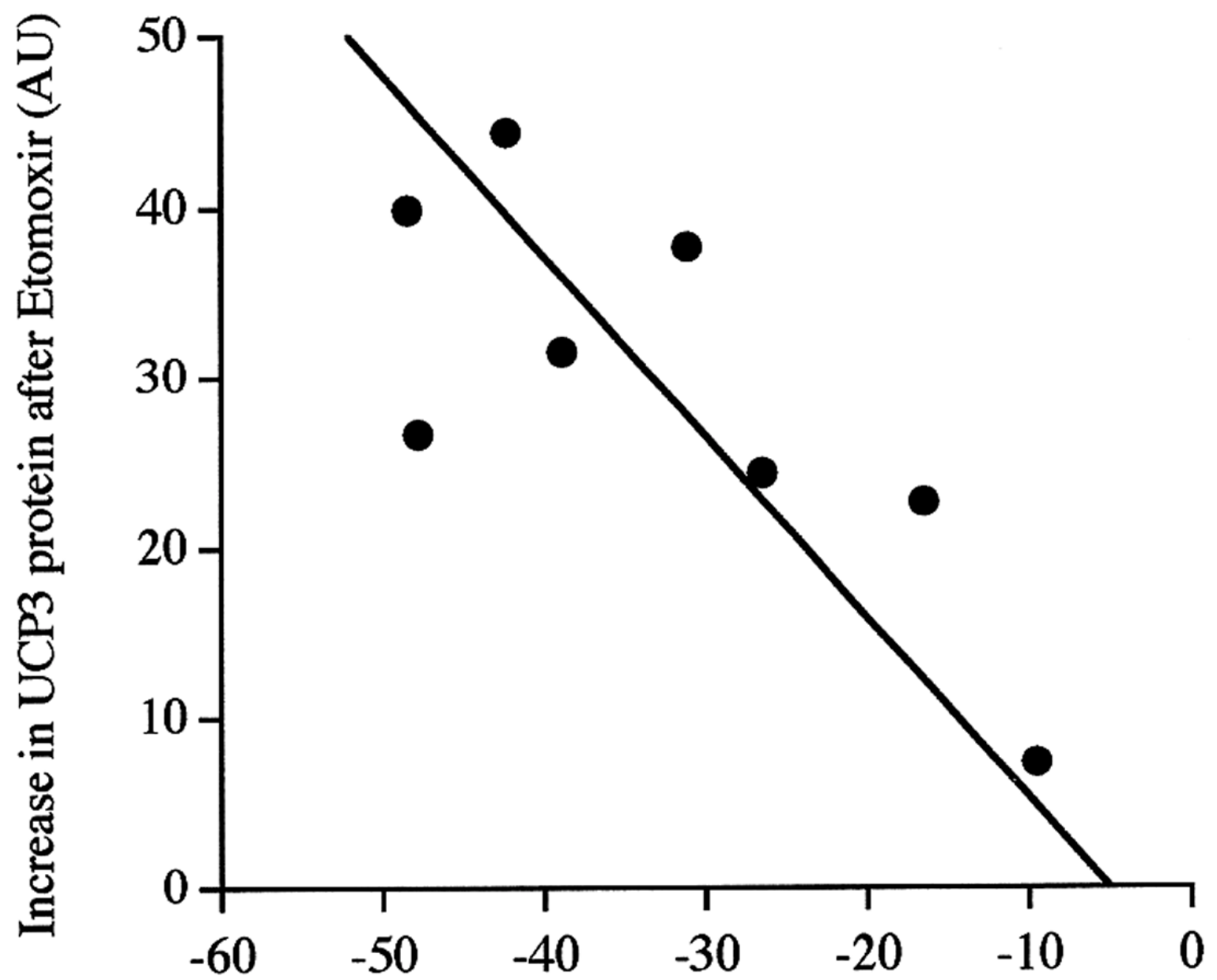

Decrease in fat oxidation after Etomoxir (g/24 hour)

Figure 3. Increase in UCP3 protein content as a function of the degree of inhibition of fat oxidation by Etomoxir. 
Fig. 4
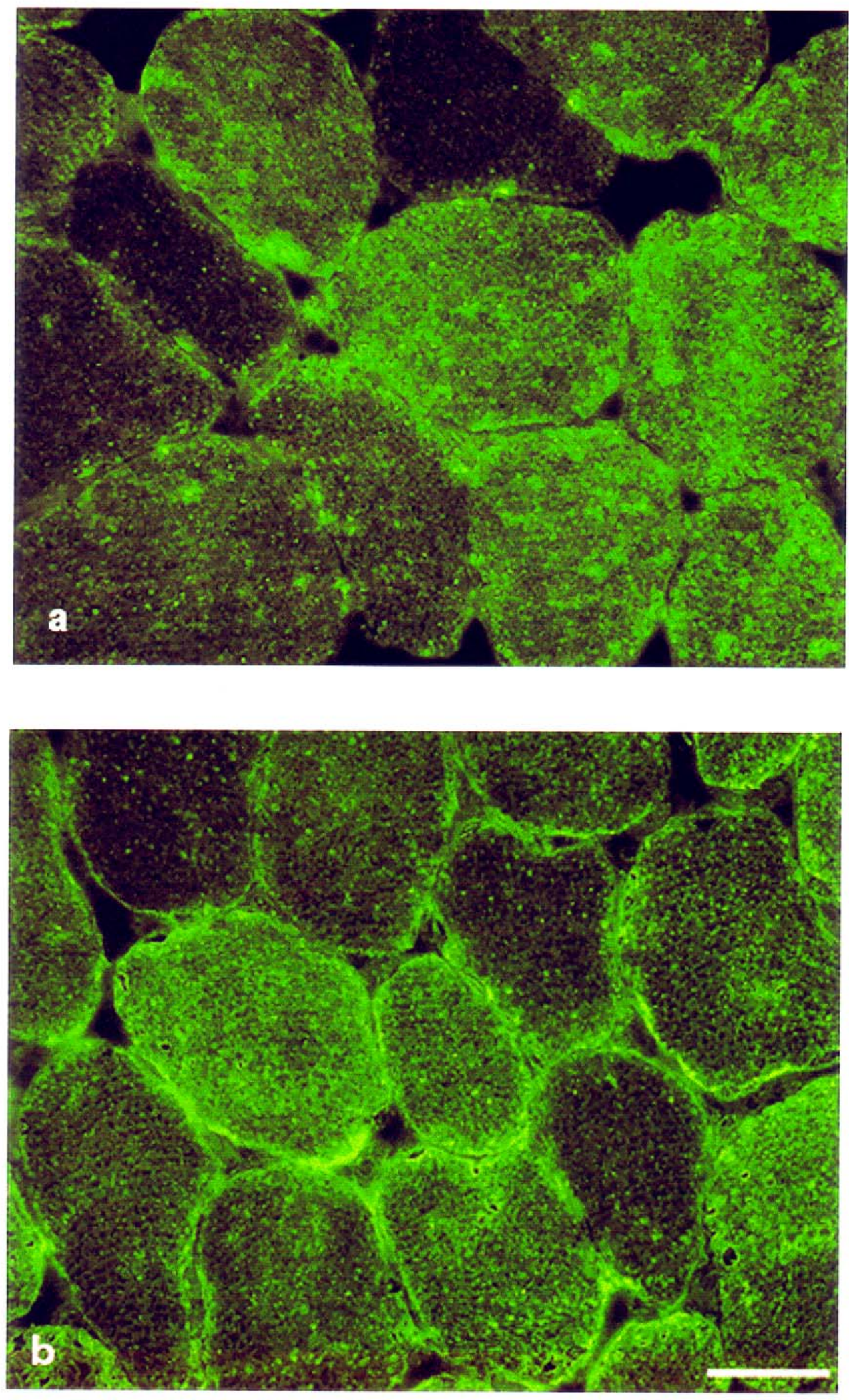

Figure 4. Immunofluorescent staining of GLUT4 in cross sections of fasting $\mathrm{m}$. vastus lateralis samples. After a) placebo and b) Etomoxir, showing increased sarcolemmal staining after Etomoxir. Bar represents $50 \mu \mathrm{m}$. 